\title{
Metody remineralizacji wczesnych zmian próchnicowych - przegląd piśmiennictwa
}

\section{Remineralizing methods in early caries lesions - review of the literature}

\author{
Paweł Berczyński ${ }^{1}$ Anna Gmerek², Jadwiga Buczkowska-Radlińska \\ ${ }^{1}$ Katedra i Zakład Stomatologii Zachowawczej i Endodoncji Pomorskiego Uniwersytetu Medycznego w Szczecinie \\ ul. Powstańców Wlkp. 72, 70-111 Szczecin \\ Kierownik: prof. dr hab. n. med. Jadwiga Buczkowska-Radlińska
}

${ }^{2}$ Zakład Stomatologii Zachowawczej Przedklinicznej i Endodoncji Przedklinicznej Pomorskiego Uniwersytetu Medycznego w Szczecinie ul. Powstańców Wlkp. 72, 70-111 Szczecin

Kierownik: prof. dr hab. n. med. Mariusz Lipski

\section{SUMMARY}

Early diagnosis and treatment of early caries lesions are the basic tenets of minimally invasive dentistry. One of the key elements of a biological approach is the usage of remineralizing agents, which are great alternative to surgical intervention.
This article shows a review of the literature concering materials used for the treatment of early caries lesions.

Key words: early caries, remineralizing agents, minimally invasive dentistry.

\section{STRESZCZENIE}

Wczesna diagnoza i leczenie plam próchnicowych stanowią podstawę stomatologii minimalnie inwazyjnej. Kluczowym elementem biologicznego podejścia do terapii wczesnych zmian próchnicowych jest stosowanie preparatów do remineralizacji, będących doskonałą alternatywą dla interwencji chirurgicznej.
W pracy przedstawiono przegląd piśmiennictwa dotyczący dostępnych materiałów stosowanych do leczenia próchnicy początkowej szkliwa.

Słowa kluczowe: próchnica początkowa, preparaty do remineralizacji, stomatologia minimalnie inwazyjna.

\section{WSTĘP}

Rozwój współczesnych metod diagnostyki choroby próchnicowej tkanek twardych zęba przyczynił się do diagnozowania tej patologii w jej najwcześniejszym stadium - plamy próchnicowej (caries incipiens, macula alba, macula cariosa, ang. early caries lesion).

Wczesna zmiana próchnicowa dostrzegalna jest klinicznie jako białe, nieprzezierne, mętne pole, o barwie odróżniającej je od sąsiedniego półprzeziernego szkliwa. Brak połysku jest wynikiem utraty powierzchniowego szkliwa, a biały kolor wewnętrznej porowatości. W tym stadium utrata substancji mineralnych nie może być wykryta, ponieważ szkliwo jest twarde i nie wykazuje ubytku.

W środowisku jamy ustnej fizykochemiczna integralność szkliwa zależy od składu chemicznego otaczających je płynów, czyli śliny i płynnej fazy płytki nazębnej. Czynnikami decydującymi o stabilności apatytów szkliwa jest pH oraz stężenie jonów: wapnia, fosforowych i fluorkowych. Przy ekspozycji na kwasy początkowo jony $\mathrm{H}^{+}$wiązane są przez bufory śliny oraz płynu płytki, ale po całkowitym ich wyczerpaniu następuje obniżenie $\mathrm{pH}$. Istotą procesu powstawania białej plamy jest podpowierzchniowa demineralizacja, zachodząca przy pH wodnej fazy w przedziale 4,5-5,5. Wówczas rozpuszczany jest hydroksyapatyt szkliwa (pH krytyczne 5,5), a powstaje fluoroapatyt (pH krytyczne 4,5), tworząc wysoko zmineralizowaną warstwę powierzchniową zmiany, pokrywającą podpowierzchniową demineralizację. Aby powstał fluorohydroksyapatyt, konieczna jest obecność jonów fluorkowych w ślinie [1]. Wczesna zmiana próchnicowa, obserwowana w mikroskopie skaningowym, wykazuje charakterystyczną budowę i składa się z 4 warstw: powierzchniowej, centralnej, ciemnej i przezroczystej. Pierwsza pokrywa powierzchnię wczesnej zmiany próchnicowej, jest wysoko zmineralizowana i strukturą przypomina zdrowe szkliwo. Objętość porów w tej warstwie wynosi 1\% i taka sama jest utrata substancji mineralnych. Warstwa centralna (body of the lesion) stanowi korpus zmiany, który jest częścią najstarszą i najbardziej aktywną, gdzie objętość porów waha się pomiędzy $5 \%$ obwodowo a $25 \%$ w części środkowej. Warstwa ciemna charakteryzuje się występowaniem różnej wielkości porów (2-4\%) i ubytkiem substancji mineralnych $2-5 \%$. Ostatnia warstwa, licząc od strony powierzchni, nie występuje we wszystkich wczesnych zmianach próchnicowych. Sąsiaduje ze zdrowym szkliwem i wykazuje utratę substancji mineralnych w granicach $1-2 \%$ oraz wzrost porowatości o 1\% [2].

Za kolor zmiany odpowiedzialne jest inne rozproszenie światła, w wyniku wzrostu porowatości szkliwa. Występujące 
różnice w wartościach wskaźnika załamania światła pomiędzy szkliwem nienaruszonym a szkliwem o wyższej porowatości są dostrzegalne wizualnie. Jeśli po osuszeniu powietrzem ujawni się biała plama, to mikroskopowo zmiana jest niewielka. Jednak gdy jest ona dostrzegalna już bez osuszania, świadczy to o większym zaawansowaniu. Wynika z tego, że klinicznie można w przybliżeniu ocenić stopień utraty substancji mineralnych [3].

Plama próchnicowa jako jedyne odwracalne stadium choroby próchnicowej wymaga wdrożenia postępowania remineralizacyjnego, którego istotą jest ponowne wbudowanie utraconych minerałów do podpowierzchniowej warstwy szkliwa. Zahamowanie procesu demineralizacji oraz wzrost potencjału remineralizacji są możliwe dzięki nasyceniu wodnego środowiska utraconymi jonami wapnia i fosforu.

Biologiczne podejście do wczesnej zmiany próchnicowej polega nie tylko na stosowaniu preparatów do remineralizacji, ale, co równie ważne, na modyfikacji środowiska jamy ustnej. Należy instruować pacjenta o konieczności zmniejszenia częstości spożywania węglowodanów oraz skutecznym usuwaniu płytki nazębnej [4]. Powyższe działania mają na celu przywrócenie i zachowanie równowagi pomiędzy naprzemiennie zachodzącymi cyklami demineralizacji i remineralizacji [5]. Na powierzchniach zębów z ograniczonym dostępem śliny i grubą warstwą płytki nazębnej procesy remineralizacyjne są utrudnione, dlatego lekarz przed podjęciem decyzji o wdrożeniu nieinwazyjnych metod leczenia powinien poprawnie ocenić ryzyko próchnicy i postępowanie remineralizacyjne zastosować jedynie u pacjentów z niskim ryzykiem próchnicy. Konieczność podjęcia leczenia wczesnej zmiany próchnicowej uzasadniona została badaniami in vivo, wykazującymi niski odsetek zmian ulegających samoistnej regresji pod wpływem jonów pochodzących ze śliny [6]. Lekarz dentysta podejmując decyzję o nieinwazyjnym leczeniu, staje przed obowiązkiem wyboru odpowiedniego preparatu. Idealny materiał do remineralizacji dostarcza jony wapnia i fosforu do podpowierzchniowej części demineralizacji. Należy jednak pamiętać, że nadmiar jonów wapnia może skutkować odkładaniem się kamienia nazębnego. Działanie powinno być udowodnione w warunkach kwaśnego oraz neutralnego pH, a także u pacjentów z obniżonym wydzielaniem śliny. Preparat powinien wspomagać remineralizacyjne właściwości śliny oraz działać synergistycznie $\mathrm{z}$ jonami fluoru [7].

\section{WYTRAWIANIE POWIERZCHNI}

Plama próchnicowa ze względu na odkładanie się minerałów na powierzchni zmiany charakteryzuje się większym stopniem zmineralizowania jej zewnętrznej części oraz mniejszą porowatością. Powoduje to zablokowanie dostępu jonów wapniowych i fosforanowych do centralnej części zmiany i skutkuje niepełną remineralizacją. Wytrawianie zmienionego szkliwa, ograniczone tylko do cienkiej, zewnętrznej warstwy powierzchniowej, powoduje jej usunięcie i odsłonięcie dróg dyfuzji dla procesów de- i remineralizacji oraz zwiększenie powierzchni szkliwa, co przyczynia się do wzrostu skuteczności podjętych działań [8]. Al-Khateeb i wsp. [9] i Tandon i wsp. [10] wykazali, że wytrawianie białych plam 37\% kwasem ortofosforowym przez 30 s nie skutkuje nadmierną ucieczką substancji mineralnych z głębszych warstw, a w efekcie powoduje wyższy stopień redukcji głębokości zmiany, w porównaniu do plam niewytrawionych. Wstępne wytrawianie powierzchni zostało wykorzystane w metodzie infiltracji, gdzie procedura obejmuje stosowanie $15 \%$ kwasu chlorowodorowego przez 90-120 s [11]. Według wyników badań wstępne wytrawianie zdemineralizowanej powierzchni szkliwa zwiększa skuteczność środków remineralizacyjnych, ale nie prowadzi do całkowitej remineralizacji zmiany. Niedawno zwrócono uwagę na możliwość wykonania dodatkowych procedur, które mogłyby poprawić rezultaty remineralizacji $[12,13]$. Deproteinizacja z użyciem $5,25 \%$ podchlorynu sodu poprzedzająca wytrawianie i osuszanie zmiany za pomocą alkoholu wymagają przeprowadzenia dalszych badań.

Dostępne preparaty do remineralizacji można podzielić na: fluorkowe, niefluorkowe i mieszane.

\section{PREPARATY FLUORKOWE}

Zasadniczym mechanizmem kariostatycznego działania fluoru jest jego poerupcyjne działanie egzogenne. W zależności od stężenia zastosowanego miejscowo preparatu w środowisku jamy ustnej zachodzą 2 różne reakcje fluoru ze szkliwem powstaje fluorohydroksyapatyt i/lub fluorek wapnia. Tworzenie fluorohydroksyapatytu zachodzi wtedy, gdy stężenie fluoru jest niskie (<50 ppm). Taka sytuacja ma miejsce w przypadku codziennego stosowania pasty z fluorem. Pomimo nagłego wzrostu ilości fluorków w jamie ustnej po zastosowaniu pasty, ich stężenie szybko spada, aby utrzymać się przez kilka godzin na poziomie 0,03-0,1 ppm - wystarczającym do wspomagania remineralizacji [14]. Fluorek wapnia powstaje, gdy stężenie fluoru jest duże (>100 ppm), co ma miejsce w przypadku stosowania profesjonalnych płynów, lakierów i pianek z fluorem. Fluorek wapnia jest prawie nierozpuszczalny w ślinie przy obojętnym pH i może pozostawać na powierzchni zęba przez wiele tygodni po miejscowej aplikacji fluoru. Depozyty $\mathrm{CaF}_{2}$ działają jako kontrolowany przez pH rezerwuar, z którego fluor jest uwalniany podczas spadku $\mathrm{pH}$ spowodowanego obecnością kwasów [15].

Najbardziej popularnymi związkami fluoru stosowanymi jako składniki roztworów, pianek i żeli do profesjonalnej profilaktyki choroby próchnicowej są: fluorek sodu (NaF), zakwaszony fosforan fluoru (APF), fluorek cyny $\left(\mathrm{SnF}_{2}\right)$ oraz aminofluorek.

\section{PREPARATY NIEFLUORKOWE}

Niefluorkowe czynniki remineralizujące można podzielić na 2 grupy: oparte na jonach wapnia i preparaty niezawierające wapnia. 


\section{AMORFICZNY FOSFORAN WAPNIA}

Amorficzny fosforan wapnia (amorphous calcium phosphateACP) jest związkiem otrzymywanym z połączenia 2 soli: siarczanu wapnia i fosforanu potasu, które na etapie przechowywania muszą być oddzielone od siebie. W momencie połączenia tworzą one kompleks ACP, który od tej chwili może zostać wbudowany w płytkę nazębną i stać się źródłem jonów potrzebnych do procesu remineralizacji [16]. Amorficzny fosforan wapnia został użyty jako składnik środków stosowanych po wybielaniu zębów, który znosi pozabiegową nadwrażliwość, jak również stanowi komponent uszczelniaczy bruzd firmy Aegis (Harry J. Bosworth Co., www.bosworth.com). W fazie badań jest również zastosowanie ACP jako składnika materiałów złożonych, który stabilizując jonową infiltrację zmiany próchnicowej, prowadzi do jej remineralizacji [17].

\section{FOSFOPEPTYD KAZEINY}

Cross $i$ wsp. wykazali, że jedna cząsteczka fosfopeptydu kazeiny (casein phosphopeptide - CPP) wiąże 25 jonów wapnia, 15 jonów fosforu oraz 5 jonów fluoru. Tak uzyskany związek jest biologicznie dostępny i może wziąć udział w procesie remineralizacji szkliwa [18]. Fosfopeptyd kazeiny ma zdolność wiązania jonów naładowanych ujemnie i dodatnio, dzięki czemu istnieje możliwość tworzenia preparatów kombinowanych, w skład których wchodzi ACP, często wzbogacony o jony fluoru (amorphous calcium fluoride phosphate - ACFP). Przewagą kompleksu CPP-ACFP jest dostępność jonów wapnia, fosforu oraz fluoru w jednym produkcie [19]. Kompleks CPP-ACP nazywany jest potocznie „płynnym szkliwem”. Materiały zawierające wymieniony kompleks, dzięki jego wiązaniu do płytki nazębnej, dostarczają substancji niezbędnych do neutralizowania kwasów produkowanych przez bakterie płytki, a także kwasów egzogennych powodujących zmiany erozyjne [20, 21].

Przeprowadzone zostały również badania dotyczące wpływu stosowania CPP na bakterie Streptococcus mutans oraz Streptococcus sobrinus, potwierdzające antybakteryjne działanie preparatu, polegające na ograniczeniu wzrostu i adherencji wymienionych drobnoustrojów. Natomiast zmiana składu płytki nazębnej wpływa na wzrost bakterii o mniejszym potencjale próchnicotwórczym [22, 23, 24]. W trakcie badań opartych na zwierzęcym modelu próchnicy zaobserwowano, że 1\% CPP-ACP redukuje aktywność próchnicy bruzd o 46\%, a próchnicę powierzchni gładkich o 55\%, co odpowiada efektowi osiąganemu przez zastosowanie preparatów zawierających 500 ppm fluoru [25, 26, 27].

Pomimo wielu badań in vitro i in vivo, niektórzy autorzy wskazują na niewystarczającą liczbę badań klinicznych potwierdzających długotrwały (powyżej 3 miesięcy) efekt remineralizacji za pośrednictwem CPP-ACP [28, 29]. W badaniu in vitro przeprowadzonym przez Comar $i$ wsp. dowiedziono braku ochronnego wpływu kompleksu CPP-ACP na demineralizację zdrowego szkliwa [30].

\section{FOSFORAN TRIWAPNIOWY}

Fosforan triwapniowy (tricalcium phosphate - TCP) występuje w 2 postaciach: $\alpha$ i $\beta$. Beta-TCP w przeciwieństwie do postaci alfa jest obiecującym materiałem do remineralizacji, ponieważ jest to preparat bioaktywny i biokompatybilny oraz stanowi fazę przejściową w procesie formowania się hydroksyapatytu (HA) [31]. Jest związkiem mniej rozpuszczalnym, powstałym z połączenia węglanu wapnia i fosforanu wapnia, częściej stosowanym w materiałach stomatologicznych. Ze względu na wysoką bioaktywność jest on łączony z innymi substancjami, w celu uzyskania jak najwyższego stopnia remineralizacji. Karlinsey i wsp. [32] połączyli TCP z kwasem fumarowym (fumaric acid - FA), tworząc sproszkowany kompleks TCP-FA. W przeprowadzonym przez autorów badaniu in vitro porównana została skuteczność remineralizacji utworzonego w eksperymencie TCP-FA (1000 ppm) i zmielonego fosforanu triwapniowego (mTCP) - 1000 ppm. Próbki szkliwa z podpowierzchniową demineralizacją testowane były w warunkach zmiennego $\mathrm{pH}$ tak, aby wiernie odtworzyć warunki panujące w jamie ustnej. W rezultacie stwierdzono, że TCP-FA posiada korzystniejszy wpływ na mikrotwardość szkliwa objętego plamą próchnicową, a także uwalnia znacznie większą ilość jonów wapnia niż mTCP. W kolejnym badaniu in vitro autorzy skupili się na właściwościach „funkcjonalnego TCP”, powstałego z połączenia $\beta$-TCP i laurylosiarczanu sodu (sodium lauryl sulfate-SLS) [33]. Powstały związek dodany został do roztworu 5000 ppm NaF, a właściwości powyższej kombinacji porównane zostały do właściwości 5000 ppm NaF. Autorzy donoszą, iż połączenie funkcjonalnego TCP (TCP-SLS) z 5000 ppm NaF skutkuje wyższym stopniem remineralizacji niż zastosowanie samego $\mathrm{NaF}$.

Głównym problemem związanym ze stosowaniem TCP jest to, że przy dostępie fluoru tworzy on kompleks fluorku wapnia na powierzchni szkliwa, co przyczynia się do zahamowania procesu remineralizacji podpowierzchniowej warstwy zmiany próchnicowej. Z tego powodu TCP powinien być stosowany w niskich stężeniach (do 1\%) lub łączony z tlenkami metali (np. $\mathrm{z}$ dwutlenkiem tytanu), aby ograniczyć interakcje z wapniem, fosforem i fluorem [34].

\section{FOSFOROKRZEMIAN WAPNIOWO-SODOWY}

Fosforokrzemian wapniowo-sodowy jest związkiem nieorganicznym, reagującym w środowisku wodnym uwolnieniem jonów wapnia, sodu i fosforu. NovaMin jest komercyjną nazwą fosforokrzemianu wapniowo-sodowego, zdolnego do uwalniania hydroksywęglanoapatytu, przypominającego swą strukturą substancję mineralną szkliwa. Formuła ta była stosowana w zaawansowanych technologiach regeneracji tkanki kostnej, dowiedziono także jej skuteczności w tworzeniu zmineralizowanej warstwy na powierzchni obnażonej zębiny [35], wykorzystano to w terapii nadwrażliwości zębiny. Pomimo konieczności przeprowadzenia większej ilości badań nad remineralizacyjnymi właściwościami bioaktywnego szkła, badacze 
potwierdzają aktywność remineralizacyjną preparatu NovaMin. Wyniki przeprowadzonych eksperymentów nie są jednak jednoznaczne. W badaniu in vitro przeprowadzonym przez Yashodhan i wsp. [36] próbki zdemineralizowanego szkliwa poddane zostały działaniu 4 różnych preparatów (fluorosilan, CPP-ACP, NovaMin, CPP-ACFP). Pasta zawierająca NovaMin wykazała redukcję głębokości demineralizacji. Była ona jednak mniej zaznaczona niż rezultaty uzyskane przez preparaty zawierające fluorosilan i CPP-ACFP. W innych badaniach in vitro [37] autorzy dowodzą, że pasta Oravive zawierająca NovaMin posiada korzystniejszy wpływ na mikrotwardość zdemineralizowanego szkliwa, w porównaniu z żelem Topex zawierającym 1,1\% NaF. W badaniach in vitro wyższość potencjału remineralizacyjnego bioaktywnego szkła zawartego w paście SHY-NM (Group Pharmaceuticals; India), w porównaniu do pasty GC Tooth Mousse (Recaldent; GCcorp; Japan) zawierającej CPP-ACP, wykazali Mehta i wsp. [38]. Ocenę skuteczności preparatu autorzy oparli na pomiarach mikrotwardości szkliwa.

\section{NANO-HYDROKSYAPATYT}

Nano-hydroksyapatyt (nano-HA), uważany za jeden z najbardziej biokompatybilnych i bioaktywnych materiałów, podobny jest w swojej strukturze do kryształów apatytów występujących w szkliwie. Powyższe właściwości skłoniły naukowców do przeprowadzenia badań nad remineralizacyjnymi możliwościami preparatów zawierających nano-HA. Tschoppe i wsp. przeprowadzili badania in vitro, wykazując wyższą efektywność remineralizacyjną past z różną procentowo zawartością nano-HA, w porównaniu do pasty zawierającej aminofluorek. Należy jednak zaznaczyć, że badania te nie uwzględniały zmian pH, ani obecności innych czynników mogących mieć wpływ na skuteczność powyższych środków w środowisku jamy ustnej [39]. Warte przytoczenia badania in vivo przeprowadzili Najibfard i wsp. [40], umieszczając zdemineralizowane próbki szkliwa w jamie ustnej 30 pacjentów. Badanie przeprowadzono techniką podwójnie ślepej próby, z użyciem pasty z 5\% nano-HA, 10\% nano-HA oraz pasty o zawartości $1100 \mathrm{ppm} \mathrm{NaF}$. W eksperymencie wykazano, że pasta z nano-HA może być skuteczną alternatywą dla pasty z fluorem, ze względu na podobne właściwości remineralizacyjne obu past, a także ich przeciwdziałanie demineralizacji.

Do odmiennych wniosków doszli Comar i wsp. [30], którzy $\mathrm{w}$ przeprowadzonym badaniu in vitro porównywali pasty zawierające nano-HA w stężeniu 10\% i 20\%, pasty z nano-HA w stężeniu 10\% i 20\% dodatkowo wzbogacone jonami fluoru oraz pastę o zawartości 0,2\% NaF. Autorzy analizowali ich skuteczność w przeciwdziałaniu demineralizacji szkliwa i zębiny w warunkach zmiennego $\mathrm{pH}$. Wyniki tych badań nie potwierdziły hamujących właściwości past z nano-HA na proces demineralizacji szkliwa, wnioskując, że najlepszym czynnikiem przeciwdziałąjącym demineralizacji jest wciąż pasta $\mathrm{z}$ fluorem.

\section{METODA INFILTRACJI WCZESNEJ ZMIANY PRÓCHNICOWEJ}

Metoda infiltracji wczesnej zmiany próchnicowej jest korzystną alternatywą dla postępowania inwazyjnego, zapewniającą ograniczenie postępu demineralizacji, a także pozwalającą na pozostawienie tkanek twardych zęba gwarantujących jego wytrzymałość.

Infiltracja wczesnej zmiany próchnicowej polega na wypełnieniu przestrzeni międzykrystalicznych zdemineralizowanego szkliwa żywicą. Uszczelniona w ten sposób plama próchnicowa jest niedostępna dla bakterii kariogennych oraz produkowanych przez nie kwasów, czego efektem jest zatrzymanie postępu choroby [41]. Stosowane w metodzie infiltracji żywice charakteryzują się niską lepkością oraz gęstością, niskim kątem zwilżania i wysokim napięciem powierzchniowym, co pozwala na penetrację materiału w głąb szkliwa dzięki siłom kapilarnym [42, 43].

Najbardziej popularnym na rynku preparatem do infiltracji jest obecnie Icon (DMG, Hamburg, Germany). Zastosowanie tego preparatu składa się z 3 faz, które rozpoczyna się 2-minutowym wytrawieniem powierzchni zdemineralizowanego szkliwa za pomocą Icon Etch, zawierającym w swym składzie 15\% kwas solny, pirogeniczny kwas krzemowy oraz substancje powierzchniowo czynne. Po wypłukaniu wytrawiacza następuje faza osuszenia zmiany, gdzie oprócz strumienia powietrza z dmuchawki stosowany jest Icon Dry (99\% etanol). Zasadnicza infiltracja składnikiem Icon Infiltrant (żywica TEGDMA) obejmuje dwukrotną aplikację preparatu oraz jego polimeryzację z użyciem światła lampy [44]. Niewątpliwą zaletą metody infiltracji jest korzystny efekt estetyczny, polegający na maskowaniu białych plam, co zostało udowodnione w badaniach in vitro [45, 46] oraz klinicznie [47, 48]. Przywrócenie naturalnego koloru zęba po zastosowaniu infiltracji żywicą wynika z faktu, że mikropory w szkliwie wypełnione zostają materiałem, którego wskaźnik refrakcji $(1,475)$ jest bardziej zbliżony do wskaźnika refrakcji szkliwa $(1,65)$ niż wskaźniki wody lub powietrza. Schmidlin i wsp. zbadali również właściwości ochronne infiltrantów (Icon) wobec zdrowego szkliwa, narażonego na czynniki demineralizujące, nie potwierdzając takich właściwości w badaniu [49]. Powyższą metodę można uznać za łącznik pomiędzy postępowaniem prewencyjnym a odtwórczym w odniesieniu do plamy próchnicowej.

\section{PODSUMOWANIE}

Najlepszą strategią zapobiegania próchnicy jest ograniczanie procesów demineralizacji oraz wspomaganie procesów remineralizacji. Nowoczesna stomatologia minimalnie inwazyjna skupia się na metodach leczenia pozwalających na maksymalną oszczędność tkanek twardych zęba. Dostępność preparatów do remineralizacji i infiltracji wczesnych zmian próchnicowych pozwala na zastąpienie interwencji chirurgicznej leczeniem nieinwazyjnym. Należy pamiętać, że wszystkie procedury powinny być przeprowadzone w porozumieniu z pacjentem, którego zaangażowanie w leczenie jest nieodzownym elementem sukcesu terapeutycznego. 


\section{PIŚMIENNICTWO}

1. Kaczmarek U.: Mechanizmy kariostatyczne fluoru. Czas Stomatol. 2005, $58,6$.

2. Piesiak-Pańczyszyn D., Czajczyńska-Waszkiewicz A., Kaczmarek U.: Analiza porównawcza ultrastrukturalnego obrazu i składu chemicznego wczesnej zmiany próchnicowej i zdrowych tkanek twardych zębów. Dent Med Probl. 2005, 42 (3), 443-448.

3. Kaczmarek U.: Patologia próchnicy. In: Stomatologia zachowawcza z endodoncją. Zarys kliniczny. Eds: Z. Jańczuk, U. Kaczmarek, M. Lipski. PZWL, Warszawa 2014, 222.

4. Murdoch-Kinch C.A., McLean M.E.: Minimally invasive dentistry. J Am Dent Assoc. 2003, 134 (1), 87-95.

5. Kaczmarek U.: Minimalnie interwencyjne leczenie stomatologiczne - przegląd piśmiennictwa. Czas Stomatol. 2007, 60 (6), 367-376.

6. Mattousch T.J., Van der Veen M.H., Zentner A.: Caries lesions after orthodontic treatment followed by quantitative light-induced fluorescence: a 2-year follow-up. Eur J Orthod. 2007, 29 (3), 294-298.

7. Jefferies S.R.: Advances in remineralization for early caries lesions: a comprehensive review. Compen Contin Educ Dent. 2014, 35 (4), 237-243.

8. Piesiak-Pańczyszyn D., Kaczmarek U., Woźniak J.: Wpływ wytrawiania powierzchni wczesnej zmiany próchnicowej na proces jej leczenia z użyciem różnych preparatów remineralizacyjnych - badania in vitro. Czas Stomatol. 2005, 58 (9), 620-627.

9. Al-Khateeb S., Exterkate R., Angmar-Mansson B., Ten Cate B.: Effect of acid-etching on remineralization of enamel white spot lesions. Acta Odontol Scand. 2000, 58 (1), 31-36.

10. Tandon S., Mathew T.A.: Effect of acid-etching on fluoride-treated caries-like lesions of enamel: a SEM study. ASDC J Dent Child. 1997, 64 (5), 344-348.

11. Meyer-Lueckel H., Paris S., Kielbassa A.M.: Surface layer erosion of natural caries lesions with phosphoric and hydrochloric acid gels in preparation for resin infiltration. Caries Res. 2007, 41, 223-230.

12. Gray G.B., Shellis P.: Infiltration of resin into white spot caries-like lesions of enamel: an in vitro study. Eur J Prosthodont Restor Dent. 2002, $10,27-32$.

13. Espinosa R., Valencia R., Uribe M., Ceja I., Saadia M.: Enamel deproteinization and its effect on acid etching: An in vitro study. J Clin Pediatr Dent. 2008, 33, 13-19.

14. Grocholewicz K., Tomasik M., Chlubek D., Samujło D.: Zmiany zawartości fluorków w ślinie po zastosowaniu fluorkowej pasty do zębów. Met Fluoru. 2002, 10, 96-101.

15. Szczepańska J.: Współczesne poglądy na profilaktykę fluorkową - niektóre apsekty kariostatycznego działania fluorków. Nowa Stom. 2003, 2, 80-83.

16. Tung M.S., Eichmilier F.C.: Dental applications of amorphous calcium phosphates. J Clin Dent. 2003, 10, 1-6.

17. Langhorst S.E., O’Donnell J.N., Skrtic D.: In vitro remineralization of enamel by polymeric amorphous calcium phosphate composite: quantitative microradiographic study. Dent Mater. 2009, 25 (7), 884-891.

18. Cross K.J., Hug N.L., Palamara J.E., Perich J.W., Reynolds E.C.: Physicochemical characterization of casein phosphopeptide-amorphous calcium phosphate nanocomplexes. J Biol Chem. 2005, 280 (15), 15362-15369.

19. Aimutis W.R.: Bioactive properties of milk proteins with particular focus on anticariogenesis. J Nutr. 2004, 134 (4), 989-995.

20. Mielczarek A., Aluchna M., Kwiatkowska A.: Wpływ wybranych materiałów na remineralizację zmian erozyjnych. Nowa Stom. 2008, 2, 34-38.

21. Reynolds E.C.: Remineralization of enamel subsurface lesions by casein phosphopeptide-stabilized calcium phosphate solutions. J Dent Res. 1997, 76 (9), 1587-1595.

22. Nongonierma A.B., Fitzgerald R.J.: Biofunctional properties of caseinophosphopeptides in the oral cavity. Caries Res. 2012, 46 (3), 234-267.

23. Schüpbach P., Neeser J.R., Golliard M., Rouvet M., Guggenheim B.: Incorporation of caseinoglycomacropeptide and caseinophosphopeptide into the salivary pellicle inhibits adherence of mutans streptococci. J Dent Res. 1996, 75 (10), 1779-1788.

24. Rose R.K.: Binding characteristics of Streptococcus mutans for calcium and casein phosphopeptide. Caries Res. 2000, 34 (5), 427-431.

25. Rao A., Malhotra N.: The role of remineralizing agents in dentistry: a review. Compend Contin Educ Dent. 2011, 32 (6), 26-33.
26. Reynolds E.C., Cain C.J., Webber F.L., Black C.L., Riley P.F., Johnson I.H. et al.: Anticariogenicity of calcium phosphate complexes of tryptie casein phosphopeptides in the rat. J Dent Res. 1995, 74 (6), 1272-1279.

27. Gupta R., Prakash V.: CPP-ACP complex as a new adjunctive agent for remineralisation: a review. Oral Health Prev Dent. 2011, 9 (2), 151-165.

28. Li J., Xie X., Wang Y., Yin W., Antoun J.S., Farella M. et al.: Long-term remineralizing effect of casein phosphopeptide-amorphous calcium phosphate(CPP-ACP) on early caries lesions in vivo. A systematic review. J Dent. 2014, 42 (7), 769-777.

29. Azarpazhooh A., Limeback H.: Clinical efficacy of casein derivatives: a systematic review of the literature. J Am Dent Assoc. 2008, 139 (7), 915-924.

30. Comar P.L., Souza M.B., Gracindo F.L., Buzalaf A.R., Magalhãe A.C.: Impact of experimental nano-HAP pastes on bovine enamel and dentin submitted to a pH cycling model. Braz Dent J. 2013, 24 (3), 273-278.

31. Tung M.S.: Calcium phosphates: structures, composition, solubility and stability. In: Calcium phosphates in biological and industrial systems. Springer, Norwel 1998, 1-20.

32. Karlinsey R.L., Mackey A.C., Walker E.R., Frederick K.E.: Preparation, characterization and in vitro efficacy of an acid-modified $\beta$-TCP material for dental hard-tissue remineralization. Acta Biomater. 2010, 6 (3), 969-978.

33. Karlinsey R.L., Mackey A.C., Walker E.R., Frederick K.E.: Surfactant-modified $\beta$-TCP: structure, properties, and in vitro remineralization of subsurface enamel lesions. J Mater Sci Mater Med. 2010, 21 (7), 2009-2020.

34. Walsh L.J.: Contemporary technologies for remineralization therapy: A review. Int Dent SA. 2009, 11, 6, 6-16.

35. Burwell A., Jennings D., Muscle D., Greenspan D.C.: Novamin and dentin hypersensitivity-in vitro evidence of efficacy. J Clin Dent. 2010, 21, 66-71.

36. Yashodhan M.B., Nandini K., Pavan K.C., Aditi K., Aravind N.K.: Prevention of enamel demineralization during orthodontic treatment: An in vitro comparative study. Orthodontics (Chic.). 2013, 14 (1), 22-29.

37. Vahid Golpayegani M., Sohrabi A., Biria M., Ansari G.: Remineralization effect of topical novamin versus sodium fluoride $(1.1 \%)$ on caries-like lesions in permanent teeth. J Dent. 2012, 9 (1), 68-75.

38. Mehta A.B., Kumari V., Jose R., Izadikhah V.: Remineralization potential of bioactive glass and casein phosphopeptide-amorphous calcium phosphate on initial carious lesion: An in-vitro pH-cycling study. J Conserv Dent. 2014, 17 (1), 3-7.

39. Tschoppe P., Zandim D.L., Martus P., Kielbassa A.M.: Enamel and dentine remineralization by nano-hydroxyapatite toothpastes. J Dent. 2011, 39, $430-437$.

40. Najibfard K., Ramalingam K., Chedjieu I., Amaechi B.T.: Remineralization of early caries by a nano-hydroxyapatite dentifrice. J Clin Dent. 2011, 22, 1-5.

41. Kielbassa M.A., Ulrich I., Treven L., Mueller J.: An updated review on the resin infiltration technique of incipient proximal enamel lesions. Medicine in Evolution. 2010, 16 (4), 3-15.

42. Turska-Szybka A., Olczak-Kowalczyk D., Andrzejczuk M., Lewandowska M., Gozdowski D.: Infiltracja żywicą naturalnych plam próchnicowych na powierzchniach gładkich zębów mlecznych - badania in vitro. Dent Med Probl. 2014, 51 (3), 308-317.

43. Meyer-Lueckel H., Paris S., Mueller J., Colfen H., Kielbassa A.M.: Influence of the application time on the penetration of different dental adhesives and a fissure sealant into artificial subsurface lesions in bovine enamel. Dent Mater. 2006, 22, 22-28.

44. Icon DMG. Instrukcja użycia.

45. Paris S., Schwendicke F., Keltsch J., Dorfer C., Meyer-Lueckel H.: Masking of white spot lesions by resin infiltration in vitro. J Dent. 2013, 41 (Suppl 5), 28-34.

46. Rocha Gomes Torres C., Buhler Borges A., Marcondes Sarmento Torres L., Silva Gomes I., Simoes de Oliveira R.: Effect of caries infiltration technique and fluoride therapy on the colour masking of white spot lesions. J Dent. 2011, 39 (3), 202-207.

47. Gugnani N., Pandit K.I., Gupta M., Josan R.: Caries infiltration of noncavitated white spot lesions: A novel approach for immediate esthetic improvement. Contemp Clin Dent. 2012, 3, 199-202.

48. Paris S., Hopfenmuller W., Meyer-Lueckel H.: Resin infiltration of caries lesions: an efficacy randomized trial. J Dental Res. 2010, 89, 823-826.

49. Schmidlin P.R., Sener B., Attin T., Wiegand A.: Protection of sound enamel and artificial enamel lesions against demineralisation: Caries infiltrant versus adhesive. J Dent. 2012, 40 (10), 851-856. 